\title{
Variance Analysis of Expatriate Pre-Hospital Provider Training in Bahrain
}

\author{
Moza M Alnoaimi $\mathbb{D}^{1,2}$, Alexander Hart ${ }^{1,3}$, Fadi Issa ${ }^{1,4}$, Attila Hertelendy ${ }^{1,5}$, Amalia Voskanyan', \\ Gregory Ciottone ${ }^{1,4}$
}

'Department of Emergency Medicine, Disaster Medicine Fellowship, Beth Israel Deaconess Medical Centre (BIDMC), Boston, MA, USA; ${ }^{2}$ Department of Emergency Medicine, Bahrain Defence Force Royal Medical Services Military Hospital, Riffa, Bahrain; ${ }^{3}$ Department of Emergency Medicine, Hartford Hospital, University of Connecticut School of Medicine, Hartford, CT, USA; ${ }^{4}$ Harvard Medical School, Harvard University, Boston, MA, USA; ${ }^{5}$ Department of Information Systems and Business Analytics, College of Business, Florida International University, Miami, FL, USA

Correspondence: Moza M Alnoaimi, Fellow, Beth Israel Deaconess Medical Centre (BIDMC) Disaster Medicine fellowship, Department of Emergency Medicine, BIDMC, Harvard Medical School, 330 Brookline Avenue, Boston, MA, USA, Email dr.mozaalnoaimi@yahoo.com; m_alnuaimi_08@hotmail.com

Introduction: The absence of local Emergency Medical Services (EMS) educational programs in Bahrain has given rise to an EMS workforce comprised predominantly of expatriate personnel with varying educational backgrounds that require further training before being licensed as EMS providers in Bahrain.

Methods: A qualitative variance analysis was performed comparing desired core competencies for EMS practice in neighbouring Saudi Arabia, used as a comparator for Bahrain, with core competencies extracted from national curricula of the major countries from which expatriate providers originate.

Results: Major core competencies not covered by the expatriate providers' curricula were identified as follows: working in an autonomous environment, requiring different critical thinking and decision-making skills, assessment and treatment during transportation, disaster response, EMS knowledge base, and coping with the different stressors of the prehospital environment.

Conclusion: These results can form the basis for additional customized training programs for expatriate EMS providers working in Bahrain, with the goal of improving and standardizing EMS care in the country.

Keywords: core competencies, emergency medical services, paramedics, pre-hospital, registered nurses, training

\section{Introduction}

The importance of Emergency Medical Services (EMS) training and development stems from the significant role EMS plays in the healthcare system. The role of an EMS provider varies depending on where the provider is working, but during an emergency, all EMS providers are responsible for early response, proper initial assessment, intervention and stabilization, and medical transportation to definitive care. ${ }^{1}$ Optimizing care in the pre-hospital setting brings about better patient outcomes, especially in time-sensitive, critical conditions, such as out-of-hospital cardiac arrest and trauma. ${ }^{2,3}$

In Bahrain, the recent launch of the National Ambulance Project (NAP) in June 2019 has marked a turning point from the previously disjointed hospital-based system to a national centralized system. This aligns with a rapid expansion and advancement in the quality of the Bahraini healthcare system. All the national ambulance units provide [ALS] services and follow the Anglo-American system. ${ }^{4}$ The NAP is standardizing EMS care throughout the country, with the goal of reducing response times and improving outcomes, with a focus on cardiac and trauma patients. ${ }^{4}$

Despite the great projected benefits, one of the challenges facing the project is the lack of EMS educational programs in Bahrain. ${ }^{4}$ EMS training is available in the neighbouring Kingdom of Saudi Arabia, where some Bahraini paramedics have obtained their bachelor's degree. However, the lack of fully trained Bahraini practitioners has resulted in recruitment of foreign pre-hospital providers. The majority of prehospital providers in Bahrain are not paramedics, but nurses from India and the Philippines. ${ }^{5-10}$ These providers typically have a nursing bachelor's degree from their home country and are then required to complete courses in Pre-Hospital Trauma Life Support [PHTLS], Advanced Cardiac Life 
Support [ACLS], Pediatric Advanced Life Support [PALS], and Basic Life Support [BLS] before being licensed as an ambulance nurse in Bahrain. ${ }^{4,11}$

A number of countries use nurses as part of their prehospital provider team, such as the Gulf Cooperation Council (GCC) countries, Sweden, the Netherlands, and the United States, to name a few. ${ }^{4,12-15}$ Systems vary in their utilization of nurses either as sole providers, as ALS providers, or for critical care and air transport. ${ }^{15,16}$ Some systems require those nurses to have working experience in critical care and/or an emergency department, and some require them to go through Emergency Medical Technician (EMT) bridge training before being able to work as a pre-hospital provider. ${ }^{14-17}$ No such bridging program currently exists or is required in Bahrain.

Whether a paramedic or a nurse, to be able to deliver safe and adequate service, EMS providers are expected to hold a specific set of core competencies that help them carry-out their responsibilities and fulfil their roles. Those core competencies can serve as a benchmark against which EMS personnel can be evaluated.

As there are no currently recognized set of competencies specific to practice in Bahrain, adopting the Saudi Arabian EMS core competencies is likely the most appropriate method of addressing local Bahraini medical needs. Given the geographic location, population demographics, and health system similarities between Bahrain and Saudi Arabia, the provision of EMS in the two nations requires similar skills from providers, so dissimilarities in land area and population between Saudi Arabia and Bahrain certainly reflect differences in some of the needs but are counterweighted by similarities in disease prevalence, cultural, religious, social and economic factors, as well as similarities in healthcare system infrastructure and the many challenges that face it. ${ }^{18}$ While there are no published national standards for EMS training in Saudi Arabia, a set of core competencies for EMS practice in Saudi Arabia from a recently published work was used as the standard for comparison in this study. ${ }^{19}$

This study aims to identify variations in the most common training programs of EMS providers in Bahrain and will highlight gaps in the training of expatriate prehospital providers in comparison to the Saudi Arabian standards, so they can be addressed by continuing education, which will continue the process of standardizing EMS in Bahrain. Additionally, India and the Philippines send expatriate nurses to numerous countries and these nurses work in the prehospital setting internationally but do not always have specific prehospital training. ${ }^{20-22}$ The set of core competencies suggested here could aid in the creation of continuing education for these providers across an international spectrum.

\section{Methods}

This was a qualitative, descriptive comparison of the core competencies of the 3 types of programs where the majority of prehospital providers in Bahrain are trained: paramedic training in Saudi Arabia, nursing training in India, and nursing training in the Philippines. The Saudi Arabian core competencies used in the comparison were extracted from a recently published work, which brought together healthcare professionals responsible for EMS provision and training in the Kingdom to create what is called The Saudi ParamEdic Competency Scale (SPECS) model. This model is the product of six separate studies including literature review, an Expert Delphi study, a national study with a large professional sample size and an advanced multivariate analysis. ${ }^{19}$

This set of Saudi Arabian core competencies was used as the standard for comparison due to the lack of any EMS training programs or published core competencies for Bahrain, the similarities between EMS practice in the two countries and the fact that prospective Bahraini EMS providers are sent to be trained in Saudi universities (Table 1). The study team removed competencies, which only pertain to the Umrah and Hajj, as these are a unique set of competencies for practice in Saudi Arabia.

National core competency curriculum documents for nursing practice from India and the Philippines were identified with a literature search using web-based search engines, as these are the two major contributors of expatriate EMS providers in Bahrain. ${ }^{4,23}$ For the Philippines, core competencies are outlined in the 2012 National Nursing Core Competency Standards, published by the Professional Regulatory Board of Nursing in the Philippines (Appendix 1). These core competencies are implemented and utilized throughout nursing education, licensing, and nursing service appraisal in the Philippines. ${ }^{24}$ For India, core competencies were extracted from the Indian Nursing Council's - which is the national qualifying and regulatory body for nurses and nursing education in India - bachelor's degree syllabus for nursing (Appendix 2) ${ }^{25,26}$ 
Table I Saudi Core Competencies for EMS Practice*

\begin{tabular}{|c|c|}
\hline \multirow[t]{9}{*}{ PROFESSIONALISM } & I. Be able to practice within the legal and ethical boundaries of the profession \\
\hline & 2. Be able to maintain appropriate and effective safety procedures \\
\hline & 3. Be able to maintain the appropriate personal characteristics of being trustworthy and accountable \\
\hline & 4. Be able to provide care according to evidence based practice. \\
\hline & 5. Be able to work as an autonomous professional with high levels of personal professional judgment. \\
\hline & 6. Be able to work in different transportation modes. \\
\hline & 7. Be committed to a process of continuous lifelong learning and professional development. \\
\hline & 8. Be able to maintain good coping skills and deal with stressful situations. \\
\hline & 9. Be flexible in learning from different sources, including guidance from colleagues. \\
\hline \multirow[t]{6}{*}{ PREPAREDNESS } & 10. Be able to prepare for and manage disasters and terrorist incidents \\
\hline & II. Be Able to effectively practice during Umrah and Hajj \\
\hline & 12. Be able to practice with appropriate Islamic values \\
\hline & 13. Be able to maintain involvement with public and community health \\
\hline & 14. Be able to demonstrate English proficiency to an adequate level for professional communication. \\
\hline & 15. Be able to demonstrate an understanding of new technologies for clinical practice. \\
\hline \multirow[t]{5}{*}{ COMMUNICATION } & 16. Be able to effectively communicate information verbally and non-verbally to patients, colleagues, and others. \\
\hline & 17. Be able to work as part of a team in a collaborative and professional approach. \\
\hline & 18. Be able to practice respectfully in a non-discriminatory manner. \\
\hline & 19. Be able to demonstrate leadership skills. \\
\hline & 20. Be information literate by having the capacity to search and apply information. \\
\hline \multirow[t]{4}{*}{ CLINICAL } & 2I. Be able to provide appropriate and effective clinical care. \\
\hline & 22. Have the theoretical knowledge and key concepts in the EMS profession. \\
\hline & 23. Be able to conduct appropriate decision making and critical thinking. \\
\hline & $\begin{array}{l}\text { 24. Be able to problem-solve by assessing professional issues and calling upon the required experience and knowledge to } \\
\text { resolve them. }\end{array}$ \\
\hline \multirow[t]{3}{*}{ PERSONAL } & 25. Understand the need to maintain an appropriate level of physical and mental fitness \\
\hline & 26. Be able to manage personal emotions and those of patients and relatives. \\
\hline & 27. Be able to maintain appropriate level of training through different professional courses. \\
\hline
\end{tabular}

Notes: *These Saudi Arabian competencies are used as a stand in for Bahraini training. Adapted with permission from Alshammari, T. M. M. (2020). The Development of Empirically Based Core Competencies for Emergency Medical Services in Saudi Arabia. ${ }^{19}$

Two authors reviewed the competencies in their entirety. They extracted any item from the Saudi Arabian core competencies, which were also not listed in the Indian or Philippine sets of competencies. A third author reviewed any areas of disagreement.

Any Saudi Arabian core competencies that were not covered in either of the two nursing core competencies are listed and described. Competencies solely covered in one of the two nursing core competencies are listed and described. A qualitative 
trend analysis of the Saudi Arabian core competencies, which are not covered by the other two programs, was performed to determine a needs analysis for continuing medical education of these practitioners for practice in Bahrain.

This research did not require approval of an Institutional Review Board or an Ethics Committee as this is not Human Subject Research.

\section{Result}

Although some competencies were at least partially fulfilled by both expatriate training programs, some important competencies were fulfilled by neither. Each program at least partially fulfilled some competencies not included in the other (Table 2).

Saudi Arabian competencies at least partially covered by both the Indian and the Philippines curriculum:

The majority of curricular competencies were covered in both the Indian and Philippine curricula. These include the ability to practice ethically within the legal bounds of the profession, patient safety, professional accountability, evidencebased practice, and care informed by the religious needs of the patient. Additionally, both include education on public health, effective patient communication, professional collaboration, and leadership skills.

Saudi Arabian competencies not covered in either the Indian or the Philippines curriculums:

Given the differences in practice between in-hospital nursing and more independent pre-hospital care, it is unsurprising that neither nursing curriculum includes requirements regarding the ability to work as an autonomous professional with high levels of personal professional judgment. Nursing curricula also understandably did not include training on the ability to work in different modes of transportation, or on theoretical knowledge and key concepts in EMS. The Saudi Arabian competencies also include requirements for English proficiency, due to its use as the language of medical care in the kingdom, maintenance of physical and mental fitness, and the ability to learn from a variety of sources through flexible learning styles. ${ }^{27}$ None of these were included in either the Indian or Philippine competencies.

Saudi Arabian competencies at least partially covered by the Indian, but not the Philippine curriculum:

The Indian Nursing Council syllabus has requirements on the understanding of new technologies for clinical practice. These were not present in the Philippine core competencies.

Saudi Arabian competencies at least partially covered by the Philippine, but not the Indian curriculum:

The Philippine Nursing Core Competency Standards include training for disasters and terrorist incidents, an important feature of EMS response. They also discuss continuous learning and professional development, coping skills for stressful professional situations, and stress critical thinking in decision making, as well as requiring graduates to update professional courses such as ALS, BLS, and so on. The Indian syllabus does not address these competencies.

\section{Discussion}

This study addresses the gaps and lack of uniformity in training of expatriate EMS nurses in Bahrain, supporting the establishment of customized training programs as a step towards the standardization of pre-hospital care. The results reveal several discrepancies between the training curricula of some expatriate prehospital providers and the needs of the Bahraini EMS system. These can be divided into two categories: those which should be required prior to hiring and assessed during the hiring process, and those which can be acquired through additional pre-employment training or continuous medical education (CME). Competencies such as English proficiency, physical and mental fitness, and flexible learning abilities likely require more time and educational resources that would make sense for the Bahraini EMS system to invest in an individual, and so should be included as pre-hiring requirements. Other competencies, such as working in a variety of transportation modes, key concepts in EMS and working in a more autonomous environment can be the focus of pre-employment training of new hires. Unfortunately, PHTLS and advanced life support courses required for licensing in Bahrain are not adequate to bridge these gaps.

The Indian curriculum failed to cover some important competencies that the Philippines curriculum at least partially covered. Additional pre-employment training programs could potentially be created aimed at these gaps. Training on 
Table 2 Comparison Between Desired Core Competencies for EMS Practice in Saudi Arabia and Core Competencies from National Curricula of India and the Philippines

\begin{tabular}{|c|c|c|c|}
\hline & $\begin{array}{l}\text { Saudi Core Competencies for EMS } \\
\text { Practice }\end{array}$ & $\begin{array}{l}\text { Is it Covered in the Indian } \\
\text { Core Competencies for } \\
\text { Nursing Practice? If Yes, } \\
\text { Where? }\end{array}$ & $\begin{array}{l}\text { Is it Covered in the Philippines } \\
\text { Core Competencies for } \\
\text { Nursing Practice? If Yes, } \\
\text { Where? }\end{array}$ \\
\hline \multirow[t]{9}{*}{ PROFESSIONALISM } & $\begin{array}{l}\text { I. Be able to practice within the legal and } \\
\text { ethical boundaries of the profession }\end{array}$ & $\begin{array}{l}\text { YES } \\
(2)^{*}\end{array}$ & $\begin{array}{c}\text { YES } \\
\text { Client Care }(\mathrm{I} . \mathrm{I})^{*}\end{array}$ \\
\hline & $\begin{array}{l}\text { 2. Be able to maintain appropriate and effective } \\
\text { safety procedures }\end{array}$ & $\begin{array}{l}\text { YES } \\
(I)(8)^{*}\end{array}$ & $\begin{array}{c}\text { YES } \\
\text { Client Care (2.4)* } \\
\text { Management \& Leadership (2.I, } \\
4.6)\end{array}$ \\
\hline & $\begin{array}{l}\text { 3. Be able to maintain the appropriate personal } \\
\text { characteristics of being trustworthy and } \\
\text { accountable }\end{array}$ & $\begin{array}{l}\text { YES } \\
(2)^{*}\end{array}$ & $\begin{array}{c}\text { YES } \\
\text { Client Care }(5.4)^{*}\end{array}$ \\
\hline & $\begin{array}{l}\text { 4. Be able to provide care according to } \\
\text { evidence based practice. }\end{array}$ & $\begin{array}{l}\text { YES } \\
(10)^{*}\end{array}$ & $\begin{array}{c}\text { YES } \\
\text { Client Care (2.4)* } \\
\text { Management \& Leadership (4.6) }\end{array}$ \\
\hline & $\begin{array}{l}\text { 5. Be able to work as an autonomous } \\
\text { professional with high levels of personal } \\
\text { professional judgment. }\end{array}$ & NO & NO \\
\hline & $\begin{array}{l}\text { 6. Be able to work in different transportation } \\
\text { modes. }\end{array}$ & NO & NO \\
\hline & $\begin{array}{l}\text { 7. Be committed to a process of continuous } \\
\text { lifelong learning and professional development. }\end{array}$ & NO & $\begin{array}{c}\text { YES } \\
\text { Client Care }(5.1)^{*}\end{array}$ \\
\hline & $\begin{array}{l}\text { 8. Be able to maintain good coping skills and } \\
\text { deal with stressful situations. }\end{array}$ & NO & $\begin{array}{c}\text { PARTIAL } \\
\text { Client Care (2.4.9)* } \\
\text { Management \& Leadership (6.4) }\end{array}$ \\
\hline & $\begin{array}{l}\text { 9. Be flexible in learning from different sources, } \\
\text { including guidance from colleagues. }\end{array}$ & NO & NO \\
\hline \multirow[t]{5}{*}{ PREPAREDNESS } & $\begin{array}{l}\text { 10. Be able to prepare for and manage disasters } \\
\text { and terrorist incidents }\end{array}$ & NO & $\begin{array}{c}\text { YES } \\
\text { Client Care }(2.4 .11)^{*}\end{array}$ \\
\hline & $\begin{array}{l}\text { II. Be able to practice with appropriate Islamic } \\
\text { values }\end{array}$ & $\begin{array}{l}\text { YES } \\
(1)^{*}\end{array}$ & $\begin{array}{c}\text { YES } \\
\text { Client Care }(2.4 .1,2.4 .12)^{*}\end{array}$ \\
\hline & $\begin{array}{l}\text { 12. Be able to maintain involvement with public } \\
\text { and community health }\end{array}$ & $\begin{array}{l}\text { YES } \\
(4)^{*}\end{array}$ & $\begin{array}{c}\text { YES } \\
\text { Management \& Leadership }(6.3)^{*}\end{array}$ \\
\hline & $\begin{array}{l}\text { 13. Be able to demonstrate English proficiency } \\
\text { to an adequate level for professional } \\
\text { communication. }\end{array}$ & NO & NO \\
\hline & $\begin{array}{l}\text { 14. Be able to demonstrate an understanding of } \\
\text { new technologies for clinical practice. }\end{array}$ & $\begin{array}{l}\text { YES } \\
(5)^{*}\end{array}$ & NO \\
\hline
\end{tabular}


Table 2 (Continued).

\begin{tabular}{|c|c|c|c|}
\hline & $\begin{array}{l}\text { Saudi Core Competencies for EMS } \\
\text { Practice }\end{array}$ & $\begin{array}{l}\text { Is it Covered in the Indian } \\
\text { Core Competencies for } \\
\text { Nursing Practice? If Yes, } \\
\text { Where? }\end{array}$ & $\begin{array}{l}\text { Is it Covered in the Philippines } \\
\text { Core Competencies for } \\
\text { Nursing Practice? If Yes, } \\
\text { Where? }\end{array}$ \\
\hline \multirow[t]{5}{*}{ COMMUNICATION } & $\begin{array}{l}\text { 15. Be able to effectively communicate } \\
\text { information verbally and non-verbally to } \\
\text { patients, colleagues, and others. }\end{array}$ & $\begin{array}{l}\text { YES } \\
(6)^{*}\end{array}$ & $\begin{array}{c}\text { YES } \\
\text { Client Care }(2.1,4.1,4.2)^{*}\end{array}$ \\
\hline & $\begin{array}{l}\text { 16. Be able to work as part of a team in } \\
\text { a collaborative and professional approach. }\end{array}$ & $\begin{array}{l}\text { YES } \\
(7)^{*}\end{array}$ & $\begin{array}{c}\text { YES } \\
\text { Client Care }(4.1,4.2)^{*}\end{array}$ \\
\hline & $\begin{array}{l}\text { 17. Be able to practice respectfully in a non- } \\
\text { discriminatory manner. }\end{array}$ & $\begin{array}{l}\text { YES } \\
(6)^{*}\end{array}$ & $\begin{array}{c}\text { YES } \\
\text { Client Care }(2 . \mathrm{I})^{*}\end{array}$ \\
\hline & I8. Be able to demonstrate leadership skills. & $\begin{array}{l}\text { YES } \\
(3)^{*}\end{array}$ & $\begin{array}{c}\text { YES } \\
\text { Management \& Leadership }(\mathrm{I}, 3,5) \\
*\end{array}$ \\
\hline & $\begin{array}{l}\text { 19. Be information literate by having the } \\
\text { capacity to search and apply information. }\end{array}$ & $\begin{array}{c}\text { YES } \\
(5)(10)^{*}\end{array}$ & $\begin{array}{c}\text { YES } \\
\text { Client Care }(3 . \mathrm{I}, 3.3) * \\
\text { Research }(3 . \mathrm{I})\end{array}$ \\
\hline \multirow[t]{4}{*}{ CLINICAL } & $\begin{array}{l}\text { 20. Be able to provide appropriate and effective } \\
\text { clinical care. }\end{array}$ & $\begin{array}{l}\text { YES } \\
(1)(4)^{*}\end{array}$ & $\begin{array}{c}\text { YES } \\
\text { Client Care }(2.3,2.4 .1,2.4 .2,2.4 .8) \\
*\end{array}$ \\
\hline & $\begin{array}{l}\text { 21. Have the theoretical knowledge and key } \\
\text { concepts in the EMS profession. }\end{array}$ & NO & NO \\
\hline & $\begin{array}{l}\text { 22. Be able to conduct appropriate decision } \\
\text { making and critical thinking. }\end{array}$ & NO & $\begin{array}{c}\text { YES } \\
\text { Client Care }(I .2,2.1,4.2)^{*}\end{array}$ \\
\hline & $\begin{array}{l}\text { 23. Be able to problem-solve by assessing } \\
\text { professional issues and calling upon the } \\
\text { required experience and knowledge to resolve } \\
\text { them. }\end{array}$ & $\begin{array}{l}\text { PARTIAL } \\
(10)^{*}\end{array}$ & $\begin{array}{c}\text { YES } \\
\text { Client Care }(2.2 .5,2.4)^{*}\end{array}$ \\
\hline \multirow[t]{3}{*}{ PERSONAL } & $\begin{array}{l}\text { 24. Understand the need to maintain an } \\
\text { appropriate level of physical and mental fitness }\end{array}$ & NO & NO \\
\hline & $\begin{array}{l}\text { 25. Be able to manage personal emotions and } \\
\text { those of patients and relatives. }\end{array}$ & $\begin{array}{c}\text { PARTIAL } \\
\text { (I) address patient needs* }\end{array}$ & $\begin{array}{c}\text { PARTIAL } \\
\text { Client Care (2. 4. 9)* }\end{array}$ \\
\hline & $\begin{array}{l}\text { 26. Be able to maintain appropriate level of } \\
\text { training through different professional courses. }\end{array}$ & NO & $\begin{array}{c}\text { YES } \\
\text { Client Care }(5 . \mathrm{I})^{*}\end{array}$ \\
\hline
\end{tabular}

Notes: ${ }^{(-)}$Referenced to sections/competencies in appendices I and 2. Adapted with permission from Alshammari, T. M. M. (2020). The Development of Empirically Based Core Competencies for Emergency Medical Services in Saudi Arabia. ${ }^{19}$

these core competencies can be part of a pre-employment course customized for Indian providers, saving time and effort for providers from other localities who have had training on these topics already.

The only core competency that the Indian curriculum covered which the Philippines curriculum did not deal with knowledge of new technologies for clinical practice. This gap is likely not significant enough to require additional training, as providers from both countries must already train on the technologies used by the NAP, and as new technologies come online, all providers require ongoing CME. 
Although paramedics and registered nurses are different healthcare professions, there is an overlap in what they can do and offer. A key difference is that most nursing training is done in-hospital under the direct supervision of doctors, while paramedics are trained in the field as an autonomous provider with on-line and off-line medical directions, and rarely need more direct medical supervision. Another difference is that most nurses, unless they have experience in emergency or critical care, are not used to the intense resuscitation environment. They may also not be as comfortable with some of the life-saving procedures and interventions the ALS providers perform. For that reason, nurses may benefit from a structured education and specialized training program in the form of a pre-hospital provider course. Nevertheless, being trained to deal with patients with multiple needs, and having a broad knowledge base of different pathologies and presentations, nurses bring depth to EMS and are well suited for advanced prehospital care provision.

The majority of the EMS workforce in Bahrain are expatriate nurses who must complete advanced life support courses before being licensed as an ambulance nurse. This study compared the core competencies obtained in nursing training from the most common expatriate nations with the suggested core competencies for EMS practice in Saudi Arabia, as a stand-in for Bahrain, where no such training programs exist. There are some important core competencies, which not all expatriate nurses will have learned which could be addressed through additional training. Most prominently, working in a more autonomous environment, requiring different critical thinking and decision-making skills, assessment and treatment during transportation, disaster response, EMS knowledge base, and coping with the different stressors of the prehospital environment. All of these are likely to play a role in provider functioning and patient outcomes. Further study should be done on validating and translating these suggested competencies into a bridging program or continuing medical education.

\section{Limitation}

Despite similarities between listed core competencies, there may be enough differences in the cultural context of these varying countries to change the exact knowledge base of the trainees. For example, legal requirements for providers vary widely across countries, so a provider learning the legal framework for healthcare in India or the Philippines may not truly understand the legal context of Bahrain. This also applies to cultural and religious values and practices. Perhaps more importantly, some core competencies as written would lead to different training, given the different roles expected of paramedic and nursing trainees. The actions expected of a provider to manage disasters and terror attacks are significantly different for a nurse working in a hospital or clinic and a prehospital provider in an ambulance deployed to the scene. Safety training also varies widely depending on the context, as prehospital providers need knowledge of scene safety and road safety, while most nursing education focuses more on the hospital and outpatient settings with regard to safety. Due to these differences in objectives and cultural origins for each set of competencies, bias could not be ruled out completely, which is a limitation of this study.

Another limitation is that the comparison in this study uses high-level curriculum requirements as listed at the national level. Many educational programs use competency lists such as these as a minimum baseline, but strive to set themselves apart by teaching their trainees beyond the requirements. Thus, expatriate nurses newly hired in Bahrain may have learned additional material exceeding their respective national requirements, and some providers may have additional work experience, which enhances their readiness for practice in Bahrain.

\section{Conclusion}

These results demonstrate the variation in pre-hospital provider training in Bahrain and can help with the prioritization of supplemental and continuous medical education activities for providers. While further study is needed, this may someday lead to the creation of a local, customized, pre-employment EMS training program, improving and standardizing EMS care in Bahrain. Additionally, other nations could look at this and similar sets of competencies for bridging programs to aid their expatriate prehospital providers in their transition.

\section{Abbreviations}

EMS, Emergency Medical Services; NAP, National Ambulance Project; ALS, Advanced Life Support; PHTLS, PreHospital Trauma Life Support; ACLS, Advanced Cardiac Life Support; PALS, Pediatric Advanced Life Support; BLS, 
Basic Life Support; CME, Continuing Medical Education; GCC, Gulf Cooperation Council; EMT, Emergency Medical Technician.

\section{Acknowledgment}

The authors express their gratitude and appreciation for Dr. Talal Alshammari, lead author of "The Development of Empirically Based Core Competencies for Emergency Medical Services in Saudi Arabia" for granting permission to reproduce the Saudi core competencies outlined in the Saudi ParamEdic Competency Scale (SPECS) model, in Table 1 and 2. The authors would also like to thank the International Labor Organization for granting permission to reprint the core competencies outlined in the 2012 National Nursing Core Competency Standards, published by the Professional Regulatory Board of Nursing in the Philippines, in Appendix 1.

\section{Disclosure}

The authors report no conflicts of interest in this work.

\section{References}

1. National EMS scope of practice model. The national highway traffic safety administration; 2019. Available from: https://www.ems.gov/pdf/ National_EMS_Scope_of_Practice_Model_2019.pdf. Accessed February 16, 2022.

2. Comilla S, Rogers Mary AM, Jason D, Kellermann Arthur L. Predictors of survival from out-of-hospital cardiac arrest. Circ Cardiovasc Qual Outcomes. 2010;3(1):63-81. doi:10.1161/CIRCOUTCOMES.109.889576

3. Weltgesundheitsorganisation (Ed.). Prehospital trauma care systems. 39162_OMS_Couv.indd (who.int); 2005.

4. Abuzeyad FH, Al Qasim G, Alqasem L, Al Farras MI. Evolution of emergency medical services in the Kingdom of Bahrain. Int J Emerg Med. 2020;13. doi:10.1186/s12245-020-00280-2

5. Bahrain Mirror. National ambulance with foreign features: Bahraini paramedics threatened with dismissal; 2020.

6. Mourshed M, Lambert T. CHAPTER 2.1 gulf cooperation council health care: challenges and opportunities. Part1.fin (elsi-project.eu); 2020.

7. Policy brief for the global policy advisory council. The Gulf Cooperation Council (GCC) and health worker migration. Available from: https:// www.aspeninstitute.org/wp-content/uploads/files/content/images/GCC\%20and\%20HWM\%20Policy\%20Brief.pdf. Accessed December $23,2020$.

8. Kodoth P. Tina Kuriakose Jacob International Mobility of Nurses from Kerala (India) to the EU: prospects and Challenges with Special Reference to the Netherlands and Denmark, CARIM-India Research Report 2013/19. Available from: https://cadmus.eui.eu/bitstream/handle/1814/29481/ CARIM-India-2013\%20-\%2019.pdf?sequence=1. Accessed February 16, 2022.

9. Percot M. Indian nurses in the Gulf: two generations of female migration. Available from: https://halshs.archives-ouvertes.fr/halshs-00004458/ document. Accessed February 16, 2022.

10. Alonso-Garbayo Á, Maben J. Internationally recruited nurses from India and the Philippines in the United Kingdom: the decision to emigrate. Hum Resour Health. 2009;7:37. doi:10.1186/1478-4491-7-37

11. Healthcare professional licencing standards: Allied healthcare professional 2017, page 25. HCP_standards_Licensing requirements for Allied medical professionals v1.0 2017.pdf (nhra.bh); 2020 .

12. Suserud B-O. A new profession in the pre-hospital care field - the ambulance nurse. Nurs Crit Care. 2005;10(6):269-271. doi:10.1111/j.13621017.2005.00129.x

13. Melby V, Ryan A. Caring for older people in prehospital emergency care: can nurses make a difference? J Clin Nurs. 2005;14(9):1141-1150. doi:10.1111/j.1365-2702.2005.01222.x

14. EMS in The Netherlands: a Dutch Treat? - jems.com; 2015. Available from: https://web.archive.org/web/20150217201958/http://m.jems.com/ article/operations-protcols/ems-netherlands-dutch-treat. Accessed February 16, 2022.

15. ASTNA. Role of the RN in the out-of-hospital environment_GW.doc (ymaws.com); 2021.

16. Qualifications, orientation, competencies, and continuing education for transport nurses, ASTNA; 2015. Available from: https://web.archive.org/ web/20150122153732/http://www.astna.org/documents/Continuing_Education_Rev2012_AB.pdf. Accessed February 16, 2022.

17. EMS \& Dispatch Operations in Dubai. (1335744000). Public safety communications. Available from: https://psc.apcointl.org/2012/04/30/emsdispatch-operations-in-dubai/. Accessed February 16, 2022.

18. Raad F. Shaping health in the GCC countries.pdf. from World Bank Document; 2021.

19. Alshammari TMM. The Development of Empirically Based Core Competencies for Emergency Medical Services in Saudi Arabia [Thesis, Monash University]; 2020. Available from: https://bridges.monash.edu/articles/thesis/The_Development_of_Empirically_Based_Core_Competencies_for_ Emergency_Medical_Services_in_Saudi_Arabia/9282851. Accessed February 16, 2022.

20. Kodoth P, Jacob TK. International mobility of nurses from Kerala (India) to the EU: prospects and challenges with special reference to the Netherlands and Denmark.: 53. Mod Asian Stud. 2001;35(2):349-384. doi:10.1017/s0026749x01002037

21. Garner SL, Conroy SF, Bader SG. Nurse migration from India: a literature review. Int J Nurs Stud. 2015;52(12):1879-1890. doi:10.1016/j. ijnurstu.2015.07.003

22. Masselink LE, Daniel Lee S-Y. Government officials' representation of nurses and migration in the Philippines. Health Policy Plan. 2013;28 (1):90-99. doi:10.1093/heapol/czs028

23. Active Licensed Allied Health Professionals (nhra.bh). National health regulatory authority Bahrain, active licenced allied health professionals; 2021. 
24. Task Force on Nursing Core Competency Revisiting Project. Nursing Core Competency Standards 2012.pdf (prc.gov.ph); 2012.

25. Indian Nursing Council. BSCSyllabus_2019-20.pdf; 2020. Available from: https://www.indiannursingcouncil.org/pdf/BSCSyllabus_2019-20.pdf. Accessed February 16, 2022.

26. Indian nursing council. Available from: https://indiannursingcouncil.org/. Accessed January 30, 2022.

27. Kaliyadan F, Thalamkandathil N, Parupalli SR, Amin TT, Balaha MH, Al Bu Ali WH. English language proficiency and academic performance: a study of a medical preparatory year program in Saudi Arabia. Avicenna J Med. 2015;05(04):140-144. doi:10.4103/2231-0770.165126

\section{Publish your work in this journal}

The Open Access Emergency Medicine is an international, peer-reviewed, open access journal publishing original research, reports, editorials, reviews and commentaries on all aspects of emergency medicine. The manuscript management system is completely online and includes a very quick and fair peer-review system, which is all easy to use. Visit http://www.dovepress.com/testimonials.php to read real quotes from published authors.

Submit your manuscript here: https://www.dovepress.com/open-access-emergency-medicine-journal 